OPEN ACCESS

Edited by: Carla Mucignat,

Università degli Studi di Padova, Italy

Reviewed by:

Marco Sassoè-Pognetto, Università degli Studi di Torino, Italy Manuel A. Pombal, University of Vigo, Spain

${ }^{*}$ Correspondence: Jorge A. Larriva-Sahd jlsneuro@unam.mx

Received: 03 July 2017 Accepted: 06 November 2017 Published: 15 November 2017

Citation:

Vargas-Barroso V, Peña-Ortega $F$ and Larriva-Sahd JA (2017) Olfaction and Pheromones: Uncanonical Sensory Influences and Bulbar Interactions.

Front. Neuroanat. 11:108. doi: 10.3389/fnana.2017.00108

\section{Olfaction and Pheromones: Uncanonical Sensory Influences and Bulbar Interactions}

\author{
Víctor Vargas-Barroso, Fernando Peña-Ortega and Jorge A. Larriva-Sahd* \\ Instituto de Neurobiología, Universidad Nacional Autónoma de México, Campus Juriquilla, Querétaro, Mexico
}

The rodent main and accessory olfactory systems (AOS) are considered functionally and anatomically segregated information-processing pathways. Each system is devoted to the detection of volatile odorants and pheromones, respectively. However, a growing number of evidences supports a cooperative interaction between them. For instance, at least four non-canonical receptor families (i.e., different from olfactory and vomeronasal receptor families) have been recently discovered. These atypical receptor families are expressed in the sensory organs of the nasal cavity and furnish parallel processingpathways that detect specific stimuli and mediate specific behaviors as well. Aside from the receptor and functional diversity of these sensory modalities, they converge into a poorly understood bulbar area at the intersection of the main- main olfactory bulb (MOB) and accessory olfactory bulb (AOB) that has been termed olfactory limbus (OL). Given the intimate association the OL with specialized glomeruli (i.e., necklace and modified glomeruli) receiving uncanonical sensory afferences and its interactions with the $\mathrm{MOB}$ and $\mathrm{AOB}$, the possibility that $\mathrm{OL}$ is a site of non-olfactory and atypical vomeronasal sensory decoding is discussed.

Keywords: olfactory limbus, pheromone, olfaction, sensory convergence

\section{INTRODUCTION}

Perception of semiochemicals in macrosmatic mammals is attributed to two sub-systems: the main (MOS) and the accessory olfactory systems (AOS), which detect volatile odors and pheromones, respectively. The MOS and AOS are regarded as anatomically and functionally independent streams of information processing; however, numerous evidence supports a combined, synergic interaction (Xu et al., 2005; Mucignat-Caretta et al., 2012; Matsuo et al., 2015). Notably, dissociated vomeronasal neurons are activated by volatile odorants (Sam et al., 2001), whereas two pheromones, 2,5-dimethyl pyrazine and 2-heptanone recruit both the olfactory epithelium (OE) and the main olfactory bulb (MOB; Lin et al., 2004). Imaging studies (Xu et al., 2005) demonstrated that mice $\mathrm{MOB}$ and accessory olfactory bulb $(\mathrm{AOB})$ are activated by either odorants or pheromones. Further, genetically-induced loss-of-function of the dorsal part of the main olfactory bulb (dMOB) suggests that it mediates pheromone recognition (Matsuo et al., 2015). Here we overview first canonical interactions between olfactory and vomeronasal receptors with the $\mathrm{MOB}$ and $\mathrm{AOB}$, respectively. Then, bulbar paths for non-conventional odorants and pheromones, as well as those for other sensory systems, are outlined. Lastly, the possible role of the transition between the $\mathrm{MOB}$ and $\mathrm{AOB}$, or olfactory limbus $(\mathrm{OL})$, in integrating polymodal, i.e., non-olfactory and atypical vomeronasal, sensory information is discussed (Figure 1). 

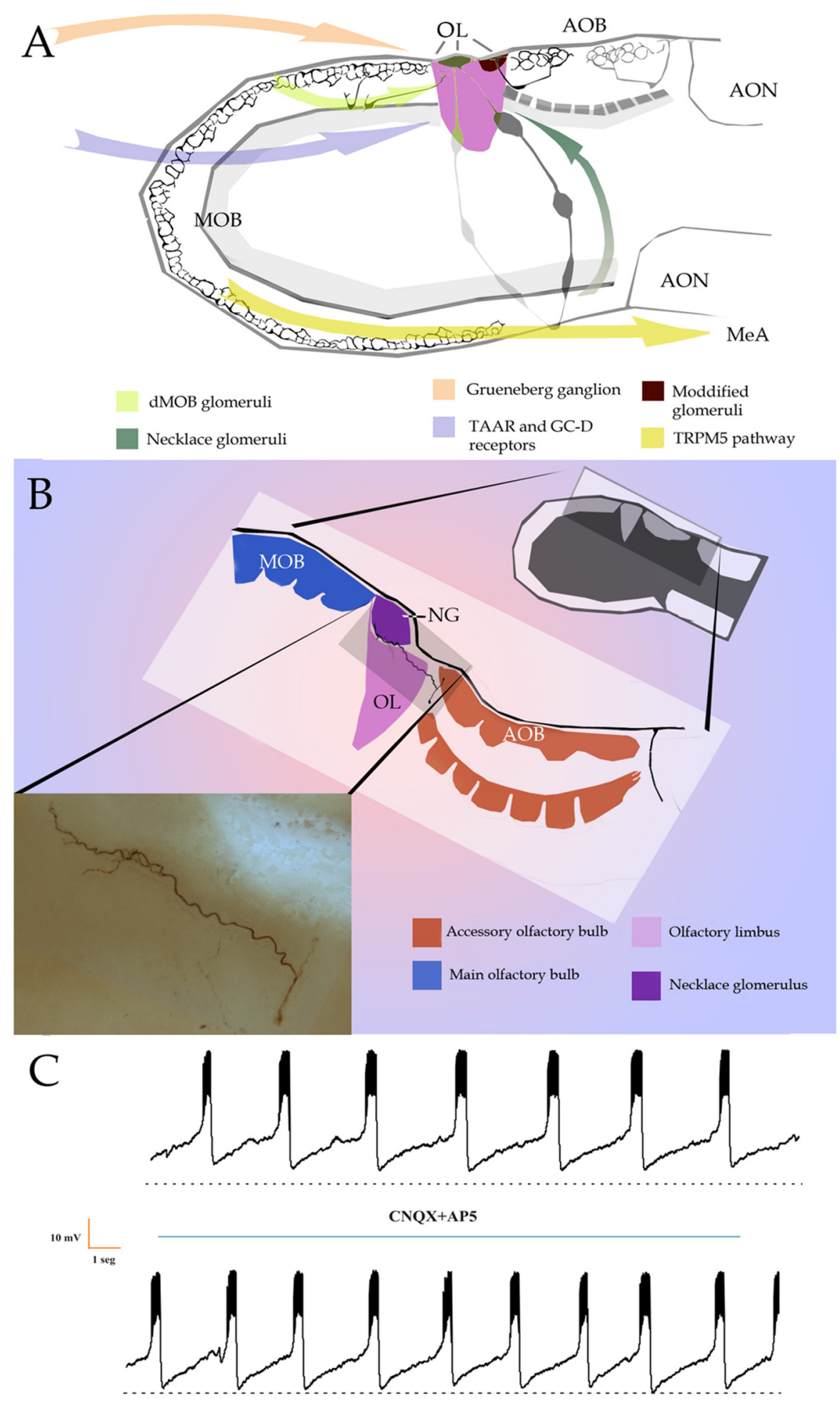

FIGURE 1 | (A) Diagramatic representation of putative bulbar and sensory inputs to the olfactory limbus (OL) and medial nucleus of the amygdala (MeA). AON, anterior olfactory nuclei; $\mathrm{AOB}$, accessory olfactory bulb; dMOB, dorsal part of the main olfactory bulb; MOB, main olfactory bulb. Arrows designate putative afferences to the OL. (B) Diagram of the OL (pink-colored) with the main (blue) and accessory (orange) olfactory bulbs. Insert at the bottom left. Light micrograph of a biocytin-injected large principal cell whose apical dendrites diverge to resolve, in the anterior accessory olfactory bulb (aAOB; orange) and necklace (deep purple) glomeruli. (C) Slice recordings of the large principal cell seen in "B", insert. To note is the numerous spikes grouped into episodic bursts in a similar fashion to that observed by pacemaker neurons. Adult rat olfactory bulb. 


\section{Olfactory and Vomeronasal Pathways}

Sensory cells (SCs) in the OE express a single olfactory receptor (OR) from a repertoire of $\sim 1000$ OR genes (Nagayama et al., 2014). Axons from SCs expressing a given receptor project to one or two glomeruli in the MOB (Nagayama et al., 2014), which is the first information processing station for the perception of odorants (Gire et al., 2012). The glomerular neuropil gathers apical dendrites of mitral (MCs) and tufted (TCs) neurons, SCs axons, and processes of periglomerular and short-axon neurons. Receptor potentials from the OE are decoded in glomeruli to generate a coherent glomerular-output (Gire et al., 2012). SCs recruit specific sets of glomeruli in the MOB, that produce a spatial representation of olfactory stimuli (Rubin and Katz, 1999). A second processing domain within the MOB is represented by reciprocal synapses between granule cells and MCs or TCs, so that the MCs and TCs out-put is modulated by granule cells (Yokoi et al., 1995). Centrally, axons from MCs and TCs project via the lateral olfactory tract to the anterior olfactory nucleus, the olfactory tubercle, the piriform cortex, the cortical amygdala and the lateral entorhinal cortex (Sosulski et al., 2011).

Regarding the AOS, it detects mainly pheromonal cues within a cigar-shaped structure: the vomeronasal organ (VNO; Holy et al., 2000) that contains four populations of SCs distributed into two layers (Dulac and Axel, 1995). An apical layer of SCs expressing members of the vomeronasal receptor family 1 (VR1; Dulac and Axel, 1995), some members of the formyl-peptide receptor family (FPR; Rivière et al., 2009) and canonical ORs (Lévai et al., 2006); whereas basal cells express the vomeronasal receptor family 2 (V2R; Herrada and Dulac, 1997; Matsunami and Buck, 1997; Ryba and Tirindelli, 1997). Regardless of receptor expression, SCs project via vomeronasal nerves to the AOB in a segregated fashion (Schwarting and Crandall, 1991) originating anterior and posterior streams that distribute in the anterior $\mathrm{AOB}(\mathrm{aAOB})$ and posterior $\mathrm{AOB}(\mathrm{pAOB}$; Larriva-Sahd, 2008). Thus, axons from SCs in the apical VNO terminate in the $\mathrm{aAOB}$, while those from the base of the VNO resolve in the pAOB (Schwarting and Crandall, 1991). Upon local information processing within the AOB, large principal cells (LPCs; LarrivaSahd, 2008) project via the lateral olfactory tract to the medial amygdala and to the hypothalamus, modulating reproductive functions (Boehm et al., 2005) and parental behavior (Wu et al., 2014).

\section{Parallel Processing in the Olfactory Bulbs: Non-canonical Paths}

SCs differing from "canonical" SCs by the receptor and/or signaling cascade, and by their glomerular targets, have recently been described. First, is a sub-population of SCs in the OE that utilizes guanylyl cyclase-D (GC-D) receptor and cGMP-stimulated phosphodiesterase 2 to transduce stimuli (Fülle et al., 1995). These unique SCs project to glomeruli confined to the caudal MOB-aAOB intersection: the so-called necklace glomeruli (NGs; Shinoda et al., 1989). The dMOB-aAOB interface, together with one or two NGs structure the OL (Larriva-Sahd, 2012; Figure 1). GC-D-OSCs that project to the NGs have been shown to detect the natriuretic peptides guanylin and uroguanylin, implying that this pathway may modulate water-ion homeostasis (Leinders-Zufall et al., 2007). Further, sensing of near-atmospheric levels of $\mathrm{CO}_{2}(\mathrm{Hu}$ et al., 2007) and socially transmitted food preferences are also mediated by this GC-D subsystem (Munger et al., 2010). Thus, in contrast to canonical MOB glomeruli, NGs are innervated by SCs expressing distinct ORs (Mombaerts et al., 1996), although both display robust interglomerular connections (Figure 1A; Shinoda et al., 1989; Cockerham et al., 2009).

It was recently demonstrated that GC-D-OSCs located in the basal recesses of the $\mathrm{OE}$ express a novel family of receptors named MS4A that, unlike that of GPCRs, span SC membrane four times (Greer et al., 2016). SCs expressing this family of receptors project their axons to the region of the NGs and seem to be activated by fatty acids and a naturally aversive pheromone (Greer et al., 2016). Interestingly, Greer et al. (2016) showed that these SCs can express more than one receptor at a time. This exciting description of the MS4A putative receptors further suggests that the OL area, including the NGs, may be regarded as a "polymodal" integrative structure as it gathers inputs from assorted sensory modalities (Figures 1A,B).

Another subset of SCs from the OE has been reported to express the transient receptor potential channel M5 (TRPM5) and to be activated by putative semiochemicals (Lin et al., 2007). Additional investigations led to the characterization of a parallel circuitry involving SCs associated with genderrelated social cues relevant for reproduction (Thompson et al., 2012). Namely, it was found that TRPM5-OSCs innervate ventro-medial MOB glomeruli and, in turn, MCs that receive these afferences convey the information transduced by TRPM5-OSCs to the medial amygdala (Figure 1; Thompson et al., 2012). The description of this specific MOB circuit mediating pheromonal effects is consistent with that of previous experiments defining that MCs in the ventral MOB are activated by socially relevant volatiles from conspecifics of the opposite sex (Kang et al., 2009). Moreover, MCs in the ventral $\mathrm{MOB}$ projected to the medial amygdala that is implicated in pheromonal responses (Kang et al., 2009, 2011). Thus, both the MOB and $\mathrm{AOB}$ are themselves capable of decoding a variety of specific signal molecules prior to projecting farther centrally. Altogether, these evidences strengthen the notion that the $\mathrm{MOB}$ and $\mathrm{AOB}$, primarily committed to the detection of odorants and water-soluble pheromones, are intrinsically capable of decoding non-canonical environmental cues.

Still another sub-population of SCs recently described in the OE expresses trace-amine associated receptors (TAARs). TAARs are GPCRs and are thought to mediate stereotyped behaviors elicited by volatile amines (Liberles and Buck, 2006). Several sub-types of TAARs have also been identified in the Grueneberg ganglion (GG; Fleischer et al., 2007), a mass of cells in the anterior nasal cavity, assumed to be involved in chemo-sensation and thermo-sensation (Fleischer et al., 2007; Chao et al., 2014). It is interesting that, in mice, activation of SCs expressing TAAR5 mediate con-specific attraction through the detection of trimethylamine (Lin et al., 2013) and TAAR4 triggers avoidance which mediated by the 


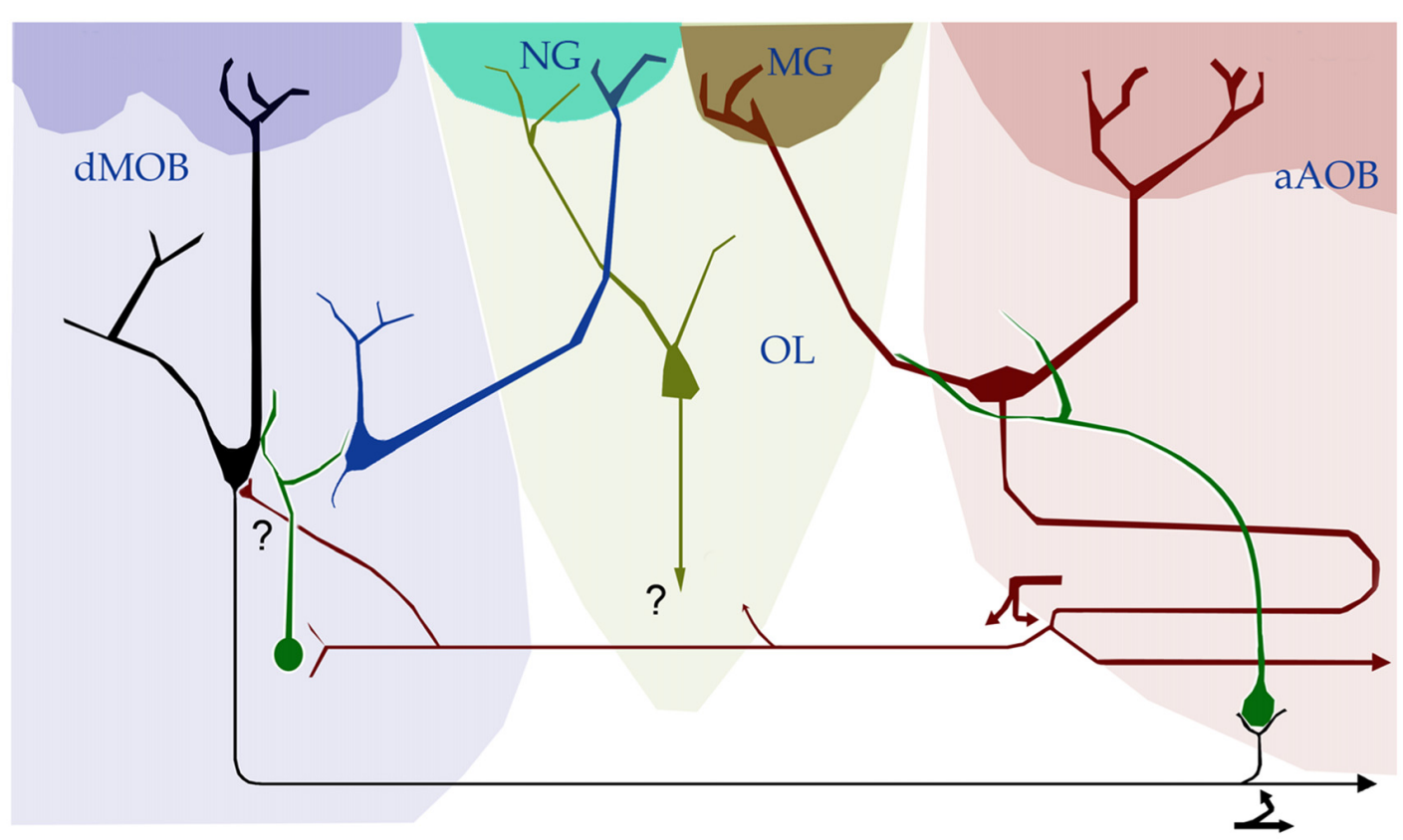

Mitral cell

Granule cells

Modified mitral

Large principal cell

Tufted cell

cell

FIGURE 2 | Position, interactions and putative connectivity of the olfactory limbus (OL, pale green). The OL lies between the caudal region of the main olfactory bulb (dMOB; pale blue) and the anterior part of the accessory olfactory bulb (aAOB; pink-colored). To note is that the necklace glomerulus (NG, turquois) receives dendrites from both a modified mitral cell in the $\mathrm{dMOB}$ and a tufted cell in the OL. A modified glomerulus (MG, dark green) receives dendrites from large principal cells (red) in the aAOB. Forked arrows designate axon collaterals of a large principal- (deep red) and a mitral-cell (black) that possibly (?) synapse with mitral- and granule-cells in the $\mathrm{dMOB}$ and with granule cells in the $\mathrm{AAOB}$, respectively.

detection of a carnivore odorant (2-phenylethylamine; Ferrero et al., 2011). Additionally, axons of TAAR-expressing SCs resolve in dMOB glomeruli (Johnson et al., 2012), a territory that receives axon collaterals from the aAOB (Figure 1; Vargas-Barroso et al., 2016). Lastly, all SCs expressing TAARs project to dorsomedial MOB glomeruli (Johnson et al., 2012; Pacifico et al., 2012); whereas all GG neurons, which also express V2r83 receptors of the V2R family (Fleischer et al., 2006), project to the NG territory (Storan and Key, 2006). In brief, axons of SCs detecting specific sorts of stimuli, thought to be implicated in a variety of innate behaviors converge in the atypical glomeruli that crown the $\mathrm{OL}$ (Figures 1A, 2).

Overall, the discovery of gene families encoding receptors that bind specific non-canonical stimuli adds up to the already complex organization of the MOS and AOS (Fülle et al., 1995; Liberles and Buck, 2006; Leinders-Zufall et al., 2007; Johnson et al., 2012; Larriva-Sahd, 2012; Thompson et al., 2012; Greer et al., 2016). Incidentally, the view that flight or fight behaviors are mediated by the MOB was unsuspected some decades ago (Raisman, 1971; Baxi et al., 2006). Hence, the notion of a clear-cut system segregation of odor and pheromone-detecting functions (Raisman, 1971; Baxi et al., 2006), should be re-evaluated.
Overlapping responses and converging pathways within the olfactory bulbs (Vargas-Barroso et al., 2016) offer alternative substrates to understand influences of uncanonical sensory cues (see above) upon the MOS and AOS (Larriva-Sahd, 2012; Nicol et al., 2014; Matsuo et al., 2015; Greer et al., 2016), as commented next.

\section{OLFACTORY LIMBUS: A CROSS ROAD?}

While integrated responses motivated by odorant and/or pheromonal stimuli are customarily attributed to axonal convergence beyond the olfactory bulb (see Mohedano-Moriano et al., 2012; Keshavarzi et al., 2015), recent evidences support the existence of an intra-bulbar network (Figure 1; Pardo-Bellver et al., 2017). A direct link between the dMOB and AOB was first suspected by experimental lesioning of the former, leading to orthograde degeneration in the latter (Larriva-Sahd, 2008); then, reciprocal interactions between them have been characterized (Vargas-Barroso et al., 2016; see Martinez-Garcia et al., 1991). Indeed, a set of LPCs is antidromically activated by stimulation of the dMOB (Vargas-Barroso et al., 2016). Moreover, dendrites from LPCs structure both AOB and OL glomeruli, suggesting that information transduced by distinct receptor families, or even 
by different sensory organs, converge into LPCs (Vargas-Barroso et al., 2016, see Figure 4i therein). Additionally, LPCs projecting to the $\mathrm{dMOB}$, exhibit electrophysiological characteristics of pace-maker neurons (Vargas-Barroso et al., 2016), suggesting that pheromones recruiting specific $\mathrm{AOB}$ glomeruli might sharpen the dMOB activity (Figure 2; see Matsuo et al., 2015).

As discussed earlier, the OL receives afferent information from a variety of sensory organs and neurons expressing all known OR families (see above; Fülle et al., 1995; Liberles and Buck, 2006; Leinders-Zufall et al., 2007; Johnson et al., 2012; Larriva-Sahd, 2012; Thompson et al., 2012; Greer et al., 2016). First, neurons expressing TAARs have been reported in the OE and the GG and shown to project to the postero-dorsal region of the MOB that includes the NGs (Storan and Key, 2006; Johnson et al., 2012; Pacifico et al., 2012). Second, GC-D-OSCs and MS4A-OSCs also project to the former region (Greer et al., 2016). Moreover, the aAOB receives projections from VIRs and from the ORs and FPRs known to be expressed in the VNO (see above; Lévai et al., 2006; Rivière et al., 2009). The receptor families mentioned, irrespective of their expression in cells of any of the sensory organs found in the nasal cavity and of their site of projection, have all been found to mediate social signals far more complex than odorant discrimination, such as thermo-sensation (Chao et al., 2014), identification of specific nutrients and/or aversive cues (Greer et al., 2016), infectious diseases (Rivière et al., 2009) and aggression (Johnson et al., 2012).

In brief, the strategical position of the OL between the $\mathrm{dMOB}$ and the $\mathrm{aAOB}$, where afferences of SCs (i.e., TAAR,

\section{REFERENCES}

Baxi, K. N., Dorries, K. M., and Eisthen, H. L. (2006). Is the vomeronasal system really specialized for detecting pheromones? Trends Neurosci. 29, 1-7. doi: 10.1016/j.tins.2005.10.002

Boehm, U., Zou, Z., and Buck, L. (2005). Feedback loops link odor and pheromone signaling with reproduction. Cell 23, 683-695. doi: 10.1016/j.cell.2005.09.027

Chao, Y.-C., Chen, C.-C., Lin, Y.-C., Breer, H., Flesicher, J., and Yang, R.-B. (2014). Receptor guanylyl cyclase- $\mathrm{G}$ is a novel thermosensory protein activated by cool temperatures. EMBO J. 34, 294-306. doi: 10.15252/embj.201489652

Cockerham, R. E., Puche, A. C., and Munger, S. (2009). Heterogeneous sensory innervation and extensive intrabulbar connections of olfactory necklace glomeruli. PLoS One 4:e4657. doi: 10.1371/journal.pone.0004657

Dulac, C., and Axel, R. (1995). A novel family of genes encoding putative pheromone receptors in mammals. Cell 83, 195-206. doi: 10.1016/00928674(95)90161-2

Ferrero, D. M., Lemon, J. K., Fluegge, D., Pashkovski, S. L., Korzan, W. J., Datta, S. R., et al. (2011). Detection and avoidance of a carnivore odor by prey. Proc. Natl. Acad. Sci. U S A 108, 11235-11240. doi: 10.1073/pnas.1103317108

Fleischer, J., Schwarzenbacher, K., Besser, S., Hass, N., and Breer, H. (2006). Olfactory receptors and signaling elements in the Grueneberg ganglion. J. Neurochem. 98, 543-554. doi: 10.1111/j.1471-4159.2006.03894.x

Fleischer, J., Schwarzenbacher, K., and Breer, H. (2007). Expression of trace amineassociated receptors in the Grueneberg ganglion. Chem. Senses 32, 623-631. doi: 10.1093/chemse/bjm032

Fülle, H. J., Vassar, R., Foster, D. C., Yang, R. B., Axel, R., and Garbers, D. L. (1995). A receptor guanylyl cyclase expressed specifically in olfactory sensory neurons. Proc. Natl. Acad. Sci. U S A 92, 3571-3575. doi: 10.1073/pnas.92.8.3571

Gire, D. H., Franks, K. M., Zak, J. D., Tanaka, K. F., Whitesell, J. D., Mulligan, A. A., et al. (2012). Mitral cells in the olfactory bulb are mainly excited through a multistep signaling path. J. Neurosci. 32, 2964-2975. doi: 10.1523/JNEUROSCI. 5580-11.2012
GC-D, MS4A, FPRs) constituting parallel processing-pathways distinctly innervate NGs or modified glomeruli (MGs, Greer et al., 1982) together with the demonstration that extensive interglomerular connections exist therein (Cockerham et al., 2009), suggests that the OL is involved in the processing of specific stimuli that signal relevant environmental cues $(\mathrm{Hu}$ et al., 2007; Leinders-Zufall et al., 2007). The latter may imply that non-olfactory and atypical vomeronasal sensory decoding may occur in the OL and, furthermore, that it is involved in the plasticity and learning of socially transmitted information, as has been shown recently (Nicol et al., 2014). Although the output(s) of the OL deserves to be investigated, it is known that dendrites organizing MGs belong to LPCs in the aAOB, which, in turn, project to the $\mathrm{dMOB}$ (Vargas-Barroso et al., 2016). The fundamental issue of whether principal cells of the OL project centrally or axons remain in the olfactory bulb, deserves further research.

\section{AUTHOR CONTRIBUTIONS}

All authors contributed equally in writing the final version of the manuscript. JL designed diagrams shown in Figures 1, 2.

\section{FUNDING}

This work was supported by Conacyt Grant Number 117 to FP-O.

Greer, P. L., Bear, D. M., Lassance, J. M., Bloom, M. L., Tsukahara, T., Pashkovski, S. L., et al. (2016). A family of non-GPCR chemosensors defines an alternative logic for mammalian olfaction. Cell 165, 1734-1748. doi: 10.1016/j. cell.2016.05.001

Greer, C. A., Stewart, W. B., Teicher, M. H., and Shepherd, G. M. (1982). Functional development of the olfactory bulb and a unique glomerular complex in the neonatal rat. J. Neurosci. 2, 1744-1759.

Herrada, G., and Dulac, C. (1997). A novel family of putative pheromone receptors in mammals with a topographically organized and sexually dimorphic distribution. Cell 90, 763-773. doi: 10.1016/s0092-8674(00)80536-x

Holy, T. E., Dulac, C., and Meister, M. (2000). Responses of vomeronasal neurons to natural stimuli. Science 289, 1569-1572. doi: 10.1126/science.289. 5484.1569

Hu, J., Zhong, C., Ding, C., Chi, Q., Walz, A., Mombaerts, P., et al. (2007). Detection of near-atmospheric concentrations of $\mathrm{CO}_{2}$ by an olfactory subsystem in the mouse. Science 317, 953-957. doi: 10.1126/science. 1144233

Johnson, M. A., Tsai, L., Roy, D. S., Valenzuela, D. H., Mosley, C., Magklara, A., et al. (2012). Neurons expressing trace-amine associated receptors project to discrete glomeruli and constitute an olfactory subsystem. Proc. Natl. Acad. Sci. U S A 109, 13410-13415. doi: 10.1073/pnas.1206724109

Kang, N., Baum, M. J., and Cherry, J. A. (2009). A direct main olfactory bulb projection to the 'vomeronasal' amygdala in female mice selectively responds to volatile pheromones from males. Eur. J. Neurosci. 29, 624-634. doi: 10.1111/j. 1460-9568.2009.06638.x

Kang, N., McCarthy, E. A., Cherry, J. A., and Baum, M. J. (2011). A sex comparison of the anatomy and function of the main olfactory bulb-medial amygdala projection in mice. Neuroscience 172, 196-204. doi: 10.1016/j.neuroscience. 2010.11.003

Keshavarzi, S., Power, J. M., Albers, E. H. H., Sullivan, R. K. S., and Sah, P. (2015). Dendritic organization of olfactory inputs to medial amygdala neurons. J. Neurosci. 35, 13020-13028. doi: 10.1523/JNEUROSCI.0627-15.2015 
Larriva-Sahd, J. (2008). The accessory olfactory bulb in the adult rat: a cytological study of its cell types, neuropil, neuronal modules and interactions with the main olfactory system. J. Comp. Neurol. 510, 309-350. doi: 10.1002/cne.21790

Larriva-Sahd, J. (2012). Cytological organization of the $\alpha$ component of the anterior olfactory nucleus and olfactory limbus. Front. Neuroanat. 6:23. doi: $10.3389 /$ fnana.2012.00023

Leinders-Zufall, T., Cockerham, R. E., Michalakis, S., Biel, M., Garbers, D. L., Reed, R. R., et al. (2007). Contribution of the receptor guanylyl cyclase GC-D to chemosensory function in the olfactory epithelium. Proc. Natl. Acad. Sci. U S A 104, 14507-14512. doi: 10.1073/pnas.0704965104

Lévai, O., Feistel, T., Breer, H., and Strotmann, J. (2006). Cells in the vomeronasal organ express odorant receptors but project to the accessory olfactory bulb. J. Comp. Neurol. 498, 476-490. doi: 10.1002/cne.21067

Liberles, S. D., and Buck, L. B. (2006). A second class of chemosensory receptors in the olfactory epithelium. Nature 442, 645-650. doi: 10.1038/nature05066

Lin, W., Arellano, J., Slotnick, B., and Restrepo, D. (2004). Odors detected by mice deficient in cyclic nucleotide-gated channel subunit A2 stimulate the main olfactory system. J. Neurosci. 24, 3703-3710. doi: 10.1523/JNEUROSCI.018804.2004

Lin, Q., Korzan, W. J., Ferrero, D. M., Chang, R. B., Roy, D. S., Buchi, M., et al. (2013). Synchronous evolution of an odor biosynthesis pathway and behavioral response. Curr. Biol. 23, 11-20. doi: 10.1016/j.cub.2012.10.047

Lin, W., Margolskee, R., Donnert, G., Hell, S. W., and Restrepo, D. (2007). Olfactory neurons expressing transient receptor potential channel M5 (TRPM5) are involved in sensing semiochemicals. Proc. Natl. Acad. Sci. U S A 7, 2471-2476. doi: 10.1073/pnas.0610201104

Martinez-Garcia, F., Olucha, F. E., Teruel, V., Llorente, M. J., and Schwerdtfeger, W. K. (1991). Afferent and efferent connections of the olfactory bulbs in the lizard Podarcis hispanica. J. Comp. Neurol. 305, 337-347. doi: 10.1002/cne.903050214

Matsunami, H., and Buck, L. (1997). A multigene family encoding a diverse array of putative pheromone receptors in mammals. Cell 90, 775-784. doi: 10.1016/s0092-8674(00)80537-1

Matsuo, T., Hattori, T., Asaba, A., Inoue, N., Kanomata, N., Kikusui, T., et al. (2015). Genetic dissection of pheromone processing reveals main olfactory system-mediated social behaviors in mice. Proc. Natl. Acad. Sci. U S A 112, E311-E320. doi: 10.1073/pnas.1416723112

Mohedano-Moriano, A., Rosa-Prieto, C., Saiz-Sánchez, D., Ubeda-Bañon, I., ProSistiaga, P., Moya-Pinilla, M., et al. (2012). Centrifugal telencephalic afferent connections to the main and accessory olfactory bulbs. Front. Neuroanat. 6:9. doi: 10.3389/fnana.2012.00019

Mombaerts, P., Wang, F., Dulac, C., Chao, S. K., Nemes, A., Mendelsohn, M., et al. (1996). Visualizing an olfactory sensory map. Cell 87, 675-686. doi: 10.1016/s0092-8674(00)81387-2

Mucignat-Caretta, C., Redaelli, M., and Caretta, A. (2012). One nose, one brain: contribution of the main and accessory olfactory system to chemosensation. Front. Neuroanat. 6:46. doi: 10.3389/fnana.2012.00046

Munger, S. D., Leinders-Zufall, T., McDougall, L. M., Cockerham, R. E., Schmid, A., Wandernoth, P., et al. (2010). An olfactory subsystem that detects carbon disulfide and mediated food-related social learning. Curr. Biol. 20, 1438-1444. doi: 10.1016/j.cub.2010.06.021

Nagayama, S., Homma, R., and Imamura, F. (2014). Neuronal organization of olfactory bulb circuits. Front. Neural Circuits 8:98. doi: 10.3389/fncir.2014. 00098

Nicol, A. U., Sanchez-Andrade, G., Collado, P., Segonds-Pichon, A., and Kendrick, K. M. (2014). Olfactory bulb encoding during learning under anesthesia. Front. Behav. Neurosci. 8:193. doi: 10.3389/fnbeh.2014.00193

Pacifico, R., Dewan, A., Cawley, D., Guo, C., and Bozza, T. (2012). An olfactory subsystem that mediates high-sensitivity detection of volatile amines. Cell Rep. 2, 76-88. doi: 10.1016/j.celrep.2012.06.006
Pardo-Bellver, C., Martínez-Bellver, S., Martínez-Garcia, F., Lanuza, E., and Teruel-Martí, V. (2017). Synchronized activity in the main and accessory olfactory bulbs and vomeronasal amygdala elicited by chemical signals in freely behaving mice. Sci. Rep. 7:9924. doi: 10.1038/s41598-017 $-10089-4$

Raisman, G. (1971). An experimental study of the projection of the amygdala to the accessory olfactory bulb and its relationship to the concept of a dual olfactory system. Exp. Brain. Res. 14, 395-408. doi: 10.1007/bf00235035

Rivière, S., Challet, L., Fluegge, D., Spehr, M., and Rodrígez, I. (2009). Formyl peptide receptor-like proteins are a novel family of vomeronasal chemosensors. Nature 459, 574-577. doi: 10.1038/nature08029

Rubin, B. D., and Katz, L. (1999). Optical imaging of odorant representations in the mammalian olfactory bulb. Neuron 23, 499-511. doi: 10.1016/s08966273(00)80803-x

Ryba, N., and Tirindelli, R. (1997). A new multigene family of putative pheromone receptors. Neuron 19, 371-379. doi: 10.1016/s0896-6273(00)80946-0

Sam, M., Vora, S., Malnic, B., Ma, W., Novotny, M. V., and Buck, L. (2001). Neuropharmacology: odorants may arouse instinctive behaviours. Nature 412:142. doi: $10.1038 / 35084137$

Schwarting, G. A., and Crandall, J. E. (1991). Subsets of olfactory and vomeronasal sensory epithelial cells and axons revealed by monoclonal antibodies to carbohydrate antigens. Brain Res. 547, 239-248. doi: 10.1016/00068993(91)90967-z

Shinoda, K., Shiotani, Y., and Osawa, Y. (1989). "Necklace olfactory glomeruli" form unique components of the rat primary olfactory system. J. Comp. Neurol. 284, 362-373. doi: $10.1002 /$ cne.902840304

Sosulski, D. L., Bloom, M. L., Cutforth, T., Axel, R., and Datta, S. R. (2011). Distinct representations of olfactory information in different cortical centres. Nature 472, 213-216. doi: 10.1038/nature09868

Storan, M. J., and Key, B. (2006). Septal organ of Grüneberg is part of the olfactory system. J. Comp. Neurol. 494, 834-844. doi: 10.1002/cne.20858

Thompson, J. A., Salcedo, E., Restrepo, D., and Finger, T. A. (2012). Secondorder input to the medial amygdala from olfactory sensory neurons expressing the transduction channel TRPM5. J. Comp. Neurol. 520, 1819-1830. doi: $10.1002 / \mathrm{cne} .23015$

Vargas-Barroso, V., Ordaz-Sánchez, B., Peña-Ortega, F., and Larriva-Sahd, J. (2016). Electrophysiological evidence for a direct link between the main and accessory bulbs in the adult rat. Front. Neurosci. 9:518. doi: 10.3389/fnins.2015. 00518

Wu, Z., Autry, A. E., Bergan, J. F., Watabe-Uchida, M., and Dulac, C. G. (2014). Galanin neurons in the medial preoptic area govern parental behaviour. Nature 509, 325-330. doi: 10.1038/nature13307

Xu, F., Schafer, M., Kida, I., Schafer, J., Liu, N., Rothman, D. L., et al. (2005). Simultaneous activation of mouse main and accessory olfactory bulbs by odors and pheromones. J. Comp. Neurol. 489, 491-500. doi: 10.1002/cne.20652

Yokoi, M., Mori, K., and Nakanishi, S. (1995). Refinement of odor molecule tuning by dendrodendritic synaptic inhibition in the olfactory bulb. Proc. Natl. Acad. Sci. U S A 92, 3371-3375. doi: 10.1073/pnas.92.8.3371

Conflict of Interest Statement: The authors declare that the research was conducted in the absence of any commercial or financial relationships that could be construed as a potential conflict of interest.

Copyright () 2017 Vargas-Barroso, Peña-Ortega and Larriva-Sahd. This is an open-access article distributed under the terms of the Creative Commons Attribution License (CC BY). The use, distribution or reproduction in other forums is permitted, provided the original author(s) or licensor are credited and that the original publication in this journal is cited, in accordance with accepted academic practice. No use, distribution or reproduction is permitted which does not comply with these terms. 